\title{
Kanser Hastalarının Yaşam Kalitesi ve Sosyal Destek Düzeylerinin Değerlendirilmesi
}

\author{
Assessment the levels of life quality and social support of the cancer patients
}

\author{
Türkan ÇALIŞKAN ${ }^{1}$, Songül DURAN ${ }^{1}$, Ayşe KARADAŞ ${ }^{1}$, Sibel ERGÜN, Özlem TEKİR ${ }^{1}$
}

${ }^{1}$ Ballkesir Üniversitesi, Balıkesir Sağlık Yüksekokulu Ebelik Bölümü, BALIKESiR

\begin{abstract}
ÖZET
Araştırma, kanser tanısı alan hastaların yaşam kalitesini, sosyal destek düzeylerini ve etkileyen faktörleri belirlemek amaciyla yapıld1.

Tanımlayıcı ve ilişki arayıcı olarak gerçekleştirilen araştırmanın örneklemini, 01 Şubat - 01 Mayıs 2010 tarihleri arasında, Balıkesir' de bir devlet hastanesinin kemoterapi ünitesinde ayaktan tedavisi yapılan ve çalışmaya katılmaya gönüllü 102 kanser tanısı almış hasta oluşturdu. Veriler araştırmacılar tarafindan hazırlanan sosyo-demografi bilgi formu, EORTC QLQ-C30 Yaşam Kalitesi Version 3.0 Türkçe Ölçeği ve Kanser Hastası Sosyal Destek Ölçeği (KHSDÖ) ile toplandı. Veriler, SPSS 21.0 paket programında değerlendirilip, istatistiksel analizde ortalama, yüzdelik dağılımları, korelasyon, t testi, One Way Anova, Bonferroni analizleri kullanıldı.

Araştırmaya katılan hastaların yaş ortalamasının 58,8 811,5 olduğu, \%58,8' inin erkek, \%60,8'inin ilköğretim mezunu, $\% 90,2$ 'sinin evli, \%34,3'ünün herhangi bir işte çalışmadığı ve \%96,1'inin sosyal güvenceye sahip olduğu belirlendi. Hastaların KHSDÖ toplam puan ortalaması $143,8 \pm 20,8$ olup, algıladığ 1 sosyal desteğin yüksek olduğu saptand. Eğitim durumu, yaşanılan yer ile KHSDÖ madde toplam puanları arasında istatistiksel olarak anlamlı fark tespit edildi $(\mathrm{p}<0.05)$. Bonferroni ileri analizinde farkın lise mezunu olan hastalar ile okur-yazar olmayan hastalar arasında ve şehirde yaşayanlar ile köyde yaşayanlar arasında olduğu saptanmıştır.

Hastaların EORTC QLQ-C30 Yaşam Kalitesi Ölçeği genel sağlık durumu alt ölçeği puan ortalaması 55.96 24.21 olarak orta düzeyde bulundu. Hastaların fonksiyonel ölçek bölümünden en yüksek puanı emosyonel fonksiyondan, en düşük puanı da uğraş fonksiyonundan aldıkları tespit edildi. Semptom ölçeği bölümünde ise en yüksek puan ortalaması maddi zorluk maddesinde görülürken, en yoğun görülen üç semptom yorgunluk, iştahsızlık, uykusuzluk olarak belirlendi.

KHSDÖ ölçeği toplam puanı ile yaşam kalitesi ölçeği genel sağlık durumu alt ölçeği ve fonksiyonel ölçek alt ölçeği puanları arasında pozitif yönde anlamlı bir ilişki, semptom ölçeği ile arasında negatif yönde anlamlı bir ilişki bulunmuştur. Hastaların sosyal destek düzeyi arttıkça yaşam kaliteleri yükselmekte, sosyal destek düzeyi azaldıkça ise yaşam kalitelerinin düşmekte olduğu belirlendi.

Kanser hastalarının yaşam kalitelerinin orta düzeyde olduğu, hastaların ailesinden algıladığı sosyal desteğin yüksek olduğu, sosyal destek düzeyi arttıkça yaşam kalitesinin de arttığı saptanmıştır.
\end{abstract}

Anahtar Kelimeler: Kanser, Yaşam Kalitesi, Sosyal Destek

\section{ABSTRACT}

This study aimed to investigate the quality of life, the social support levels and the influential factors of these two in patients diagnosed with cancer.

The sample of this descriptive and correlational study consisted of 102 cancer outpatients who attended the chemotherapy unit of a state hospital in Balıkesir between 01.01.2010 and 01.05.2010 and who volunteered to participate in the study. The data were collected using a socio-demographic information form prepared by the researchers, EORTC QLQ-C30 Quality of Life Scale Turkish Version 3.0 and Cancer Social Support Scale (CSSS). The data were analyzed using a SPSS 21.0 package program and statistical analyses included the mean, percentage distribution, correlation, $t$ test, one Way Anova and Bonferroni analyses.

The mean age of the patients was $58,8 \pm 11,5$ years, $58,8 \%$ of the patients were male, $60,8 \%$ of the patients were primary school graduate, $90,2 \%$ were married, $34,3 \%$ of the patients were unemployed and $96,1 \%$ of the patients were covered under social security. The mean CSSS score of the patients was 143,8 $\pm 20,8$ and they had a high perception of social support. Statistically significant differences were found between CSSS total scores and educational state and residential areas of the patients $(\mathrm{p}<0.05)$.

Further analysis with Bonferroni indicated that this difference was related to the differences between high school graduates and illiterate patients and between the patients living in urban areas and the patients living in rural areas.

The patients had moderate EORTC QLQ-C30 Quality of Life Scale scores with a mean score of 55.96 \pm 24.21 . Among the function subscales, the patients obtained the highest scores from the emotional functioning subscale and the lowest scores from the occupational functioning subscale. Symptom subscale indicated that the highest mean score was in the financial difficulty item while fatigue, loss of appetite and insomnia were the three most common symptoms.

A positive correlation was found between the total score of the CSSS scale and global health state and functional subscale scores, while a negative correlation was found between the total score of the CSSS scale and symptom subscale scores. While the quality of life was improved in correlation with an increase in social support level, lower levels of social support were associated with a decrease in the quality of life.

The level of the the quality of life of cancer patients was moderate, they had a high perception of social support from their family and the quality of life was improved in correlation with an increase in social support level.

Keywords: Cancer, Quality of Life, Social Support 


\section{GíRIŞ}

Kanser, hücrelerin kontrolsüz büyümesi ve anormal şekilde yayılımı ile karakterize olan hastalıklar grubunu tanımlamaktadır. Kanser, yüzyılın başlarında ölüme neden olan hastalıklar arasında yedinci ve sekizinci sıralarda yer alırken, bugün dünyanın birçok ülkesinde ve Türkiye'de kalp hastalıklarından sonra ikinci sırada yer almaktadır (1).

Kanser tanısının konması ve tedaviye başlanması, birey ve ailenin fiziksel, emosyonel, sosyal ve ekonomik dengelerini alt üst etmekte yaşamdan doyum almalarını engellemekte ve yaşam kalitesini azaltmaktadır (2). Kanser hastalığının adı, adının verdiği korku, gelecek kaygısı, hastalık sürecinde yaşanabileceklerin yarattı̆ğ stres ve tedaviye bağlı istenmeyen etkiler, hasta ve hasta yakınlarının yaşam kalitesini önemli derecede etkilemektedir. Tüm bu olumsuzluklara ve tedavi nedeniyle olan yan etkilere rağmen tedavi süresince ve tedavi sonrasında hastaların yaşam kalitelerinin iyileştirilmesi ve devamının sağlanması önemlidir (3). Sağlığa bağlı hayat kalitesi; fiziksel fonksiyon, psikolojik fonksiyon, sosyal etkileşim ve hastalık ile tedaviye bağlı semptomlar gibi dört ana maddeyi içeren çok yönlü bir kavramdır (4-5). Kanserli hastalarda hastalık sürecinden ve tedavinin yan etkilerinden kaynaklanan semptomlarla ilişkili rahatsızlıkların yaşam kalitesi üzerinde olumsuz etkilere neden olduğu ve tedavi önerilerine uyumu zorlaştırdığı saptanmıştır (6).

Kanser, fiziksel bir rahatsızlık olmasının yanı sıra, psikososyal sorunların en fazla gözlendiği durumlardan biridir. İnsanın varoluşuna iliskin sorunları da beraberinde getirerek psikolojik açıdan ciddi sorunlar doğurur. Sağlık koşullarının giderek bozulması, sıkıntıların süreklilik kazanması ve hastalıkla ilgili kaygı yaratan koşulların gittikçe artması kanser hastalarını desteğe daha çok gereksinim duyar hale getirmektedir (2). İnsanların yaşamında önemli bir yeri olan, gerektiğinde kişiye duygusal, maddi ve bilişsel yardım sağlayan tüm kişilerarası ilişkiler, sağlığı korumaya yarayan sosyal destek sistemleri şeklinde tanımlanmıştır. Birçok araştırmacı, sosyal desteklerin yaşam stresinin yarattığı zararları hafifleterek ya da dengeleyerek hastalıklara karşı tampon görevi gördüğü konusunda birleşmektedirler. Bireyler tarafindan algılanan sosyal destek sosyal ağ üyelerince sağlanan yardımların kişiye verdiği doyum olarak değerlendirilmektedir (7).

Sosyal desteğin kanser hastaları için yararlı olduğunu ve aile üyelerinden alınan duygusal destek ile kansere fiziksel ve psikolojik uyum derecesi arasında olumlu bir ilişki olduğunu belirten birçok çalışma vardır $(2,7,8)$. Sosyal destek tedavi sonrasi uyumu kolaylaştırmakta ve iyileşmenin fizyolojik mekanizmasını etkilemektedir (9). Bununda ötesinde tanı koyma aşamasında verilen sosyal destek ile uzun yaşam arasındaki ilişkiyi gösteren boylamsal araştırmalar, sosyal destek ile psikolojik uyum arasında nedensel bir ilişski bulunduğunu göstermektedir (10). Başetme becerileri, sosyal destek (8), semptomlar ve işlevsellik yaşam kalitesini etkilemektedir (11). Alınan sosyal desteğin boyutu ve içeriği kanser mortalite ve morbidetesi ile ilişkili bulunmuştur (12).

$\mathrm{Bu}$ araştırma bu verilerden yola çıkarak kanser tanısı alan hastalarda yaşam kalitesi ve sosyal destek düzeylerini belirlemek, bunları etkileyen sosyodemografik ve hastalıkla ilgili özellikleri belirlemek, uygun hemşirelik uygulamalarını geliştirmede rehber olabilecek önerileri sunmak amacıyla planlanmıştır.

\section{GEREÇ VE YÖNTEM}

Tanımlayıcı ve ilişki arayıcı olarak gerçekleştirilen araştırmanın örneklemini, 1Şubat - 1 Mayıs 2010 tarihleri arasında, Balıkesir ilinde bir devlet hastanesinin kemoterapi ünitesinde ayaktan tedavisi yapılan ve çalışmaya katılmaya gönüllü 102 kanser tanısı almış hasta oluşturdu. Veriler araştırmacılar tarafindan hazırlanan sosyo-demografik bilgi formu, 
Beser ve Öz (2003) tarafından kapsam geçerliği ve güvenirlik çalı̧̧ası yapılan EORTC QLQ-C30 (Avrupa Kanser Araştırma ve Tedavi Organizasyonu Yaşam Kalitesi Ölçeği) (3) ve Eylen (2002) tarafindan geliştirilen ve ülkemiz için geçerlilik, güvenilirliği yapılmış olan Kanser Hastası Sosyal Destek Ölçeği (KHSDÖ) (10) ile toplandi.

Sosyo-demografik Bilgi Formu: $\mathrm{Bu}$ çalş̧mada kullanılmak üzere araştırmacılar tarafından oluşturulan soru formunda kanserli bireyin yaşı, cinsiyeti, eğitim durumu, medeni durumu, iş/mesleği, sosyal güvencesi, tanısı, tanı süresi hakkında bilgi alınmasını sağlayan toplam 19 soru bulunmaktadır.

\section{Kanser Hastası Sosyal Destek Ölçeği (KHSDÖ):}

Hastaların, ailelerinden aldıklarını düşündükleri sosyal destek türünü ve düzeyini belirlemek amaciyla kullanılan Likert tipi 5 basamaklı derecelendirmeli bir ölçektir (10).

Hastaların kanser hastası sosyal destek ölçeğinden alabilecekleri toplam en düşük puan 1, en yüksek puan ise $175^{\prime}$ 'dir. Otuz beş sorudan oluşan ölçüm aracındaki maddelerin 13'ü “ $4,9,13,14,21,22,26,27,29,30$, 31 , 32, 33" olumsuz, 22'si olumlu ifadeden oluşmaktadır. Denekler her maddeyi 5'li Likert tipi ölçek üzerinde " 5 " benim durumuma çok uygun, "4" benim durumuma uygun, " 3 " benim durumuma kısmen uyuyor, "2" benim durumuma uygun değil ve "1" benim durumuma hiç uygun değil olarak değerlendirdiler. Algılanan sosyal destek puanı, olumlu maddelerden alınan puanların toplamı ile olumsuz maddelerin puanlarının ters çevrilip toplanmasından elde edilen puanların toplamına eşittir.

EORTC QLQ-C30 Yaşam Kalitesi Ölçeği: Ölçek EORTC tarafından geliştirilmiş, Beşer ve Öz tarafından kapsam geçerliği ve güvenirlik çalışması yapılmış, Cronbach alfa katsayısı, $\mathrm{r}=0,9014$ olarak bulunmuştur. EORTC QLQC30 Version 3.0 yaşam kalitesi ölçeği kanserli hastalarda tüm dünyada yaygın kullanılan bir yaşam kalitesi ölçeğidir (3). EORTC-QLQ-C30 Yaşam
Kalitesi Ölçeği genel iyilik hali, fonksiyonel güçlükler ve semptom kontrolü olmak üzere üç alt başlık ve 30 soru içermektedir. Fonksiyonel skalalar; fiziksel, rol, kognitif, emosyonel ve sosyal fonksiyonları içermektedir. Semptom skalalarında ise halsizlik, ağrı ve bulantı-kusma değerlendirilmektedir. Ayrıca dispne, insomnia, iştah kaybı, konstipasyon, diyare ve maddi zorluk durumu birer soru ile ölçülmektedir. Ölçekteki 30 maddeden ilk 28'i dörtlü likert tipi ölçektir ve maddeler Hiç: 1, Biraz: 2, Oldukça: 3, Çok: 4 puan olarak değerlendirilmektedir. Ölçeğin 29. sorusunda hastadan 1'den 7'ye kadar olan ölçek ile (1: çok kötü ve 7: mükemmel) sağlığını ve 30. soruda genel yaşam kalitesini değerlendirmesi istenmektedir. 29. ve 30. sorular genel iyilik hali alanını oluşturan sorulardır. Hastaların fonksiyonel ölçek ve genel sağlık durumu ölçeği puanının yüksek olması; semptom ölçeği puanının düşük olması ise yaşam kalitesinin yüksek olduğunu göstermektedir. $\mathrm{Bu}$ çalışmada KHSDÖ ölçeğinin alfa değeri 0.85, EORTC QLQ-C30 Yaşam Kalitesi Ölçeğinin alfa değeri 0.87 bulunmuştur.

Sosyodemografik veriler sayı ve yüzdeliklerle değerlendirilmiştir. Sosyodemografik değişkenlerle yaşam kalitesi ölçeği puanlarının karşılaştırılmasında bağımsız gruplarda $t$ testi ve varyans analizi testinden yararlanılmıştır. Sosyodemografik değişkenlerle KHSDÖ puanlarının karşılaştırılmasında varyans analizi ve Bonferroni analizlerinden yararlanılmış, yaşam kalitesi ölçeği ile KHSDÖ arasındaki ilişki korelasyon analizi ile değerlendirilmiştir.

\section{BULGULAR}

Araştırmaya katılan hastaların yaş ortalamasının 58,8 $111,5, \quad \% 58,8^{\prime}$ i erkek, \%60,8'inin ilköğretim mezunu, \%90,2'sinin evli, \%34,3'ünün herhangi bir işte çalışmadığı ve \%96,1'inin sosyal güvenceye sahip olduğu belirlendi. Hastaların \%45,1'i mide, \%34,3'ü akciğer, \%17,6'sı meme ve \%2,9'u baş boyun kanseri tanıs1 aldığı görüldü. 
Tablo 1. Hastaların EORTC QLQ-C30 Yaşam Kalitesi Puan Ortalamalarının Dağılımı

\begin{tabular}{lcc}
\hline Değişsen & Maddeler & Ortalama \pm SD \\
\hline Fonksiyonel Durum* & & $\mathbf{6 7 . 9 3} \pm \mathbf{1 9 . 1 9}$ \\
Fiziksel Fonksiyon & $01-05$ & $75.05 \pm 15.28$ \\
Rol Fonksiyon & $6-7$ & $68.13 \pm 27.05$ \\
Emosyonel Fonksiyon & $21-24$ & $86.07 \pm 22.28$ \\
Kognitif Fonksiyon (Bilişsel fonksiyon) & 20,25 & $77.61 \pm 23.51$ \\
Sosyal Fonksiyon & $26-27$ & $69.11 \pm 26.88$ \\
Global Sağlık Durumu (Genel iyilik hali) $* *$ & $\mathbf{2 9 - 3 0}$ & $\mathbf{5 5 . 9 6} \pm \mathbf{2 4 . 2 1}$ \\
Semptom Skalası*** & & $\mathbf{2 4 . 5 6} \pm \mathbf{1 6 . 1 3}$ \\
Halsizlik & $10,12,18$ & $45.53 \pm 28.85$ \\
Bulantı-Kusma & $14-15$ & $24.67 \pm 28.98$ \\
Ağrı & 9,19 & $31.69 \pm 27.40$ \\
Dispne & 8 & $33.33 \pm 35.10$ \\
İnsomnia & 11 & $34.31 \pm 34.93$ \\
İştah Kaybı & 13 & $38.88 \pm 37.54$ \\
Konstipasyon & 16 & $26.79 \pm 34.79$ \\
Diyare & 17 & $17.32 \pm 29.19$ \\
Maddi Zorluk & 28 & $50.00 \pm 38.32$ \\
\hline
\end{tabular}

*Fonksiyonel ölçke puanı; 0-100 arasında değişmektedir. Yüksek puan yüksek fonskiyonel düzeyi göstermektedir.

**Genel iyilik hali puanı; 0-100 arasında değişmektedir. Yüksek puan iyilik halini göstermektedir.

***Semptom puanı; 0-100 arasında değişmektedir. Yüksek puanlar semptomun şiddetli olduğunu göstermektedir.

Hastaların EORTC QLQ-C30 Yaşam Kalitesi Ölçeği genel sağlık durumu alt ölçeği puan ortalaması $55.96 \pm 24.21$ olarak orta düzeyde bulundu. Hastaların fonksiyonel ölçek bölümünden en yüksek puanı emosyonel fonksiyondan $(86.07 \pm 22.28)$, en düşük puanı da uğraş fonksiyonundan (68.13 \pm 27.05$)$ aldıkları tespit edildi. Semptom ölçeği bölümünde ise en yüksek puan ortalaması maddi zorluk maddesinde (50.00 \pm 38.32) görülürken, en yoğun görülen üç semptom yorgunluk, iştahsızlık, uykusuzluk olarak belirlendi.
Çalışmamızda, cinsiyet, medeni durum, gelir durumu, sosyal güvenceye sahip olma, çalışma durumu, hastanın birlikte yaşadığı kişiler ile yaşam kalitesi ölçeğinin genel iyilik hali alt ölçeği toplam puanları arasında istatistiksel olarak anlamlı bir farklılık saptanmamıştır $(\mathrm{p}>0.05)$.

Çalışmaya katılanların Kanser Hastası Sosyal Destek Ölçeği'nden ve her bir alt ölçeğinden aldıkları puan ortalamaları incelendiğinde; sosyal destek ölçeğinin puan ortalamasının $143,8 \pm 20,8$ her bir alt ölçeğinin 
sırası ile güven desteği 57,6 $\pm 10,4$; duygusal destek $50.7 \pm 7.8$; bilgi desteği $35.5 \pm 5.2$ olduğu görüldü.

Katılımcıların yaş, medeni durum, meslek/iş ile KHSDÖ madde toplam puanları arasında istatiksel açıdan anlamlı bir fark bulunmazken ( $p>0.05)$, eğitim durumu (okuryazar olmayan, okuryazar, ilköğretim, lise, üniversite mezunu) ve KHSDÖ madde toplam puanları arasında istatistiksel olarak anlamlı fark tespit edilmiştir $(\mathrm{p}<0.05)$. Lise mezunu olan hastaların okuryazar olmayanlara göre sosyal destek ölçeğinden daha yüksek puan aldığı saptanmıştır ( $\mathrm{F}=9.06$, p:.003). Ayrıca yaşanılan yer (köy, ilçe, şehir) ile KHSDÖ madde toplam puanları arasında da istatistiksel olarak anlamlı fark tespit edilmiş $\quad(\mathrm{p}<0.05)$, şehirde yaşayanların köyde yaşayanlara oranla sosyal destek ölçeğinden daha yüksek puan aldıkları saptanmıştır ( $\mathrm{F}=$ 4.78, p:.026).

Tablo 3'te EORTC QLQ-C30 yaşam kalitesi ölçeğinin kanser hastası sosyal destek arasındaki ilişkinin karşılaştırılması verilmiştir. KHSDÖ ölçeği toplam puanı ile genel sağlık durumu $(r=0.271, p=0.006)$ ve fonksiyonel ölçek puanları $(\mathrm{r}=0.239, \mathrm{p}=0.016)$ arasında istatistiksel açıdan pozitif yönde anlamlı bir ilişki, Semptom ölçeği ile $(r=.-196 \mathrm{p}=.048)$ negatif yönde anlamlı bir ilişki bulunmuştur. Genel olarak hastaların sosyal destek düzeyleri arttıkça genel sağlık durumları, fiziksel, rol, emosyonel, bilişsel fonksiyonları da artmakta; sosyal destek düzeyleri azaldıkça halsizlik semptomları da artmaktadır.

Güven desteği alt ölçeği ile genel sağlık durumu arasında istatistiksel açıdan pozitif yönde anlamlı bir ilişki, halsizlik ile negatif yönde anlamlı bir ilişki bulunmuştur $(\mathrm{p}<0.05)$. Güven desteği alan hastaların genel sağlık durumu artmakta ve bununla birlikte halsizlik semptomları azalmaktadır.

Duygusal destek alt ölçeği ile genel sağlık durumu, fiziksel fonksiyon, emosyonel fonksiyon, rol fonksiyon, uğraş fonksiyon ve bilişsel fonksiyon arasında istatistiksel açıdan pozitif yönde anlamlı bir ilişki, halsizlikve dispne arasında negatif yönde anlamlı bir iliski bulunmuştur $(\mathrm{p}<0.05)$.

Bilgi desteği ile emosyonel ve bilişsel fonksiyon arasında istatistiksel açıdan pozitif yönde anlamlı bir ilişki bulunurken uykusuzluk semptomu ile negatif yönde anlamlı bir ilişki bulunmustur $(\mathrm{p}<0.05)$. Bilgi desteği arttıkça emosyonel ve bilişsel fonksiyon durumu iyileşmekte ve uykusuzluk semptomu azalmaktadır.

Tablo 2. Hastaların Kanser Hastası Sosyal Destek Ölçeği (KHSDÖ) Puan Ortalamalarının Dağılımı

\begin{tabular}{lccc}
\hline Değişen & Ortalama \pm SD & Madde sayısı & Min-Max \\
\hline Toplam puan & $143.08 \pm 20,8$ & 35 & $35-175$ \\
Güven desteği & $57.6 \pm 10,4$ & 13 & $13-65$ \\
Duygusal destek & $50.7 \pm 7,8$ & 12 & $12-60$ \\
Bilgi desteği & $35.5 \pm 5,2$ & 10 & $10-50$ \\
\hline
\end{tabular}


Tablo 3. EORTC QLQ-C3 Yaşam Kalitesi Ölçeği ile Kanser Hastası Sosyal Destek Ölçeği Arasındaki İlişkinin Karşılaştırılması

\begin{tabular}{|c|c|c|c|c|}
\hline $\begin{array}{l}\text { EORTC QLQ-C3 Yaşam Kalitesi } \\
\text { Ölçeği }\end{array}$ & $\begin{array}{l}\text { Sosyal Destek } \\
\text { Ölçeği Toplam }\end{array}$ & Güven Desteği & $\begin{array}{l}\text { Duygusal } \\
\text { Destek }\end{array}$ & Bilgi Desteği \\
\hline Genel Sağlık Durumu & $.271^{* *}$ & $.316^{* *}$ & $.203^{*}$ & .0144 \\
\hline FONKSIYYONEL ÖLÇEK & $.239 *$ & .118 & $.320 * *$ & $.236^{*}$ \\
\hline Fiziksel fonksiyon & .181 & .128 & $.212 *$ & .147 \\
\hline Rol fonksiyon & .175 & .131 & $.207^{*}$ & .125 \\
\hline Emosyonel Fonksiyon & .186 & .064 & $.260 * *$ & $.223^{*}$ \\
\hline Kognitif Fonksiyon (Bilişsel & .191 & .093 & $.234^{*}$ & $.223^{*}$ \\
\hline fonksiyon) & .121 & .019 & $.257^{*}$ & .131 \\
\hline Sosyal Fonksiyon & & & & \\
\hline Semptom Skalası &.$-196^{*}$ & -121 & $-.221 *$ & $-.210^{*}$ \\
\hline Halsizlik & $-.204 *$ & $-.124 *$ & $-.249 *$ & -.192 \\
\hline Bulantı-Kusma & -.109 & -.084 & -.102 & -.113 \\
\hline A ğrı & -.091 & -.001 & -.164 & -.117 \\
\hline Dispne & -.109 & -.024 & $-.211^{*}$ & -.068 \\
\hline İnsomnia(Uykusuzluk) & -.127 & -.006 & -.181 & $-.246^{*}$ \\
\hline İştah Kaybı & -.139 & -.126 & -.140 & -.091 \\
\hline Konstipasyon & -.099 & -.104 & -.046 & -.117 \\
\hline Diyare & -.054 & $-.086^{*}$ & -.049 & -.028 \\
\hline Maddi Zorluk & -.031 & -.058 & -.030 & -.036 \\
\hline
\end{tabular}

** 0.01 düzeyinde anlamlı ilişki

* 0.05 düzeyinde anlamlı ilişki

\section{TARTIŞMA}

Kanser tedavisinde tek amaç, hastalığın ortadan kaldırılması değil tedavi sonrası morbiditenin azaltılarak hayat kalitesinin arttırılmasıdır. Hayat kalitesi birey üzerinde etkili olan tüm durum ve faktörleri kapsar (12). Araştırmaya katılan grubun genel sağlık durumu puan ortalaması $55.96 \pm 24.21$ 'dir (Tablo 1). Hastaların genel sağlık durumu orta düzeyde bulunmuştur.
Bıkmaz (2009) lösemi hastalarıyla yaptığı çalışmasında EORTC QLQ-C30 genel sağlık puan ortalamasını 59.76 olarak benzer şekilde orta düzeyde saptamıştır (2). Ünsal ve ark.'larının (2006) rektal kanser tanılı olgularda adjuvant tedavisinin uzun dönem yaşam kalitesi üzerine etkisini değerlendirdikleri çalışmada genel sağlık durumu puan ortalamasını 73.5 olarak saptamışlardır (13). 
Pınar ve arkadaşları jinekoloji kanserli hastalarda EORTC QLQ-C30 yaşam kalitesi ölçeği puan ortalamasını $51.54 \pm 22.20$ olarak bulmuşlardır (14). Kimura ve arkadaşları (2013) kolorektal kansere bağlı ostomili hastalarla yaptıkları çalışmada katılımcıların \% 11.11'inin yaşam kalitelerini çok kötü, \%48.6'sının kötü olarak düşündüğüni saptamışlardır (15).

$\mathrm{Bu}$ çalışmada hastaların fonksiyonel sağlık durumu iyi düzeyde bulunmuştur. Çalışmamızda hastalar fonksiyonel ölçeklerden en yüksek puanı emosyonel fonksiyondan alırken en düşük puanı da uğraş fonksiyonundan almışlardır. Semptom ölçeklerinde ise en yüksek puan ortalaması maddi zorluk maddesinde görülmüş, en yoğun görülen üç semptom yorgunluk, iştahsızlık, uykusuzluk olarak belirlenmiştir. Hastaların emosyonel fonksiyondan yüksek puan almış olması istendik bir durumdur ve bunun hastayı olumlu yönde desteklediği düşünülmektedir. Hastaların uğraş fonksiyonlarının daha düşük olması hastalığa bağlı tedavi sürecinden dolayı uğraşlara zaman ayıramamalarından kaynaklandığı düşünülebilir. Ayrıca hastalığın ve tedavinin yan etkilerine bağlı kendilerinin halsiz, yorgun hissetmelerinin de uğraş fonksiyonlarına olumsuz etki ettiği söylenebilir (2). Hastaların yorgunluk, iştahsızlık ve uykusuzluk semptomlarını daha yoğun yaşamalarının, hastalığa ve tedaviye bağlı gelişen bulantı ve kusmaya, kan değerlerindeki değişmelere ve hastalık sürecine bağlı olduğu düşünülmektedir $(2,16)$. Hastaların maddi zorluk yaşamalarının ise yoğun tedavi giderlerinin sosyal güvenceleri tarafindan tam olarak karşılanamamasına ya da gerekli bürokratik sürecin uzun olmasına (ilaç raporlarının hazırlanması vb.), tedavi ve takip sürecinde hastaların fiilen çalışamamaları sebebi ile gelir düzeylerindeki azalmaya bağlı olabileceği belirtilmiştir (2).

Ünsal ve arkadaşlarının (2006) çalışmasında hastaların rol fonksiyon puan ortalaması en yüksek, emosyonel fonksiyon puan ortalaması ise en düşük puan ortalaması olarak bulunmuştur. En yüksek ortalama semptom skorları yorgunluk ve maddi zorluk parametrelerinde bulunmuştur (13). Rab (2012) meme kanserli hastalarla yaptığı çalışmada fiziksel ve duygusal boyutu normalin altında saptamıştır (17). Ertem ve arkadaşlarının (2009) çalışmasında hastaların semptom alt grubunda en fazla halsizlik $(6.76 \pm 2.49)$ ve ağrı (3.76 \pm 1.55$)$ puanlarının yüksek olduğu (yaşam kalitesinin düştüğü) belirlenmiştir (1). Sarenmalm ve arkadaşlarının (2006) meme kanserli hastalarla yaptıkları çalışmada hastaların duygusal fonksiyonlarının fiziksel fonksiyonlardan daha düşük düzeyde olduğunu ve genel iyilik hali rol fonksiyonunun da düşük seviyede olduğunu saptamışlardır. En yaygın görülen semptomları halsizlik, uykusuzluk, ağrı, üzüntü, seksüel aktivitelerde zorluk ve ağız kuruluğu olarak saptamışlardır (16).

$\mathrm{Bu}$ araştırmada yaş, cinsiyet ve medeni durumun hastaların yaşam kalitesi üzerinde etkili olmadığı bulunmuştur ( $p>0.05$ ). Kızılcı'nın çalışmasında (1999) da benzer şekilde hastaların yaş, cinsiyet ve medeni durumunun hastaların yaşam kalitesi üzerinde etkili olmadığı bulunmuştur (18). Benzer şekilde Heydarnejad (2011) kemoterapi alan kanserli hastalarla yaptığı çalışmada yaşam kalitesi ile yaş, cinsiyet, medeni durum ve mesleğin yaşam kalitesi ile anlamlı bir ilişkinin olmadığını saptamıştır (19). Gökgöz ve arkadaşlarının (2011) meme kanserli hastalarla yaptıkları çalışmada eğitim düzeyi ile genel sağlık durumu (Yaşam kalitesi ölçeği alt boyutu) arasında anlamlı bir ilişki saptamazken, ilkokul mezunu hastaların daha iyi fiziksel fonksiyon ve beden imgesine sahip olduklarını saptamışlardır (20). Bizim çalışmamızdan farklı olarak Salonen meme kanserli hastalarla yaptığı çalışmada genç hastaların yaşlı olanlara göre daha düşük yaşam kalitesine sahip olduğunu saptamıştır (2011).

Literatürde sosyal desteğin bireyi stresli yaşam olaylarının zararlı etkilerinden korumada etkili olduğu ve hastalığın olumsuz sonuçlarına karşı tampon görevi 
gördüğü belirtilmiştir (21). Kanser tanısı ve tedavisi sosyal destek ihtiyacını arttırırken kanser olmak sosyal damgalanmaya yol açarak sosyal desteğe en çok ihtiyaç duyulan zamanda sosyal desteğe ulaşımı azaltabilir. Kanser hastalarında sosyal desteğin azalması ise yaşam kalitesinde düşüşe ve daha fazla semptom yaşanmasına yol açmaktadır (22). Literatürde aileden ve arkadaşlardan algılanan desteğin yaşam kalitesinin fiziksel ve duygusal boyutuyla pozitif ilişkide olduğu belirtilmiştir (23). Yapılan çalışmalarda meme kanserli hastalarda algılanan sosyal desteğin yaşam kalitesi ile ilişkili olduğu ve aile işleyişi ve desteğinin kansere uyum sürecinde çok önemli olduğu bildirilmiştir (21). Literatürde meme kanserli hastalarda sosyal desteğin sıkıntıları ve psikiyatrik problemleri azaltarak yaşam kalitesini arttırdığ 1 belirtilmiştir (24). Bu çalışmada hastaların sosyal destek düzeyi ölçeği toplam puanı ve alt ölçeklerinden aldıkları toplam puanı oldukça yüksek düzeyde bulunmuştur. Bizim çalışmamıza benzer olarak Dedeli ve arkadaşlarının çalışmasında da hastaların sosyal destek puanları oldukça yüksek düzeyde saptanmıştır (7). Özyurt (2014) çalışmasında hastaların ailelerinden aldıkları sosyal desteği düşük düzeyde algıladıklarını saptamıştır. Her bir alt ölçeği incelediğinde ise hastaların ailelerinden aldıkları duygusal destek düzeyini orta derecede algıladıklarını, bilgi desteğini düşük düzeyde bulduklarını ve güven desteğini ortanın üzerinde algıladıklarını belirtmiştir (25).

$\mathrm{Bu}$ çalışmada lise mezunu olan hastaların sosyal destek ölçeği madde toplam puan ortalamalarının okuryazar olmayan hastalara oranla daha yüksek düzeyde olduğu saptanmıştır. Benzer şekilde Uysal (2011) baş boyun kanserli hastalarla yaptığı çalışmada eğitim düzeyi yükseldikçe güven desteği, duygusal destek ve algılanan sosyal destek puanlarının anlamlı şekilde yükseldiğini saptamıştır (26). Eğitim düzeyi yükseldikçe aileden algılanan sosyal desteğin yükselmesinin eğitimle birlikte bireylerin sosyal ağları daha iyi kullanmalarına bağlı olabileceği düşünülmektedir.
$\mathrm{Bu}$ çalışmada yaş ile sosyal destek ölçeği puanı arasında istatiksel açıdan anlamlı bir ilişkiye rastlanmamıştır. Naseri ve Taleghani (2012) de kanser hastalarıyla yaptıkları çalışmada bizim çalışmamıza benzer olarak yaş ile sosyal destek arasında anlamlı bir ilişki saptamadıklarını belirtmişlerdir (27). Novotny ve arkadaşları (2010) çalışmalarında genç kanserli hastaların yaşlı hastalara oranla daha düşük sosyal destek ağa sahip olduklarını saptamışlardır (22).

Yine araştırma grubumuzda şehirde yaşayan hastaların Sosyal Destek ölçeği toplam madde puan ortalamalarının köyde yaşayanlara göre daha yüksek düzeyde olduğu saptanmıştır. Bunun nedeninin şehirde yaşayan hastaların hastalıkları ile baş edebilmek için sağlık hizmetlerinden yararlanmalarının daha fazla olmasına bağlı olabileceği düşünülmektedir.

Sosyal desteğin kanser hastaları için yararlı olduğunu ve aile üyelerinden alınan duygusal destek ile kansere fiziksel ve psikolojik uyum derecesi arasında olumlu bir ilişki olduğunu belirten birçok çalışma vardır (7). Bıkmaz'ın (2009) çalışmasında hastaların aile, arkadaş ve özel insandan aldıkları sosyal destek arttıkça yaşam kalitesinin fiziksel ve emosyonel boyutlarında iyileşme görüldüğü, sosyal destek azaldıkça iştahsızlık ve mali sıkıntıların arttığı saptanmıştır (2). Doğan'ın (2011) çalışmasında da benzer olarak hastaların aile desteği puan ortalaması arttıkça yaşam kalitesi ve yaşam kalitesinin alt boyutlarına ait puan ortalamaları da artmıştır (28). Bu çalışmada sosyal destek düzeyinden alınan puan arttıkça hastaların genel sağlık durumları, fiziksel, rol, emosyonel, bilişsel fonksiyonlarından aldıkları puanlar da artmakta; sosyal destek düzeyinden alınan toplam puan azaldıkça halsizlik ve uykusuzluk semptomlarından aldıkları puanlar da artmaktadır. Çalışmanın bulguları literatür ile parallellik göstermektedir.

Sağlık profesyonelleri kanserli hastalarının sağlığının iyileştirilmesinin yanısıra yaşam kalitesinin de önemini dikkate almalıdır. Yaşam kalitesinin alınan sosyal destekle ilişkisi göz önüne alındığında hastanın mevcut 
sosyal destek kaynaklarını fark etmesini ve bunları kullanabilmesini sağlamak gereklidir. Ayrıca sosyal destek kaynaklarını da arttırmanın tedavinin seyrinde önemli rol oynadığı düşünülmektedir. Bu bağlamda hemşirelerin aktif rol oynaması önem kazanmaktadır. $\mathrm{Bu}$ çalışma sonucunda sosyal desteğin yaşam kalitesini olumlu yönde etkilediği göz önüne alınırsa hastalara sosyal destek kaynaklarını fark etmelerini ve bunları kullanabilmelerini öğretmek onları olumlu yönde destekleyecektir.

\section{KAYNAKLAR}

1. Ertem E, Alkım A, Bulut S, Sevil Ü. Radyoterapi Alan Hastaların Evde Bakım Gereksinimleri ve Yaşam Kaliteleri. Maltepe Üniversitesi Hemşirelik Bilim ve Sanatı Dergisi. 2009; 2(2): 3-12.

2. Bıkmaz Z. Lösemili Hastaların Yaşam Kalitesi ve Sosyal Destek Düzeylerinin Değerlendirilmesi. Yüksek Lisans Tezi, Trakya Üniversitesi, Edirne: 2009.

3. Beser NG, Öz F. Kemoterapi Alan Lenfomalı Hastaların Anksiyete-Depresyon Düzeyleri Ve Yaşam Kaliteleri. Cumhuriyet Üniversitesi Hemşirelik Yüksek Okulu Dergisi. 2003; 7 (1): 47 58.

4. Akduman D. Larenks kanserlerini cerrahi sonuçları; evrelendirmelerinin preoperatif, intraoperatif ve postoperatif karşılaştırılması; sağkalım ve tedavi sonrası hayat kalitelerinin değerlendirilmesi. Uzmanlık Tezi, Haydarpaşa Numune Eğitim ve Araştırma Hastanesi, İstanbul: 2007.

5. Kutlu R, Çivi S, Börüban MC, Demir A. Kanserli hastalarda depresyon ve yaşam kalitesini etkileyen faktörler. Selçuk Üniv Tıp Derg. 2011; 27(3): 149153.

6. Gültekin Z, Pınar G, Pınar T, Kızıltan G, Doğan N, Algier L, Bulut I, Özyılkan Ö. Akciğer kanserli hastaların yaşam kaliteleri ve sağlık bakım hizmet beklentileri. Uluslararası Hematoloji-Onkoloji Dergisi. 2008; 2 (18): 99-106.
7. Dedeli Ö, Fadıloğlu Ç, Uslu R. Kanserli bireylerin fonksiyonel durumları ve Algıladıkları Sosyal Desteğin İncelenmesi. Türk Onkoloji Dergisi. 2008; 23(3): 132-9.

8. Usta YY. Importance of Social Support in Cancer Patients. Asian Pacific J Cancer Prev. 2012; 13: 3569-72.

9. Penedo FJ, Traeger L, Benedict C, Thomas G, Dahn RJ, Krause MH, Goodwin J. Perceived Social Support as a Predictor of Disease-Specific Quality of Life in Head-and-Neck Cancer Patients. J Support Oncol. 2012; 10(3) 119-23.

10. Eylen B. Kanser Hastası Sosyal Destek Ölçeği' nin Geçerlik, Güvenirlik ve Faktör Yapısı Üzerine Bir Çalışma. Uludağ Üniversitesi Eğitim Fakültesi Dergisi. 2002; 15(1): 109-117.

11. Helgeson VS. Cohen S. Social Support And Adjustment To Cancer: Reconciling Descriptive, Correlational, And Intervention Research. Health Psychology. 1996; 15(2): 135-48.

12. Çetin ZE. Parsiyel Larenjektomili Hastalarda Farkli Operasyon Tiplerinin Yutma Fonksiyonalrina ve Hayat Kalitesine Etkisi. Uzmanlık Tezi, Ege Üniversitesi, İzmir: 2014.

13. Ünsal D, Tunç E, Pak Y. Rektal Kanser Tanılı Olgularda Adjuvant Tedavinin Uzun Dönem Yaşam Kalitesi Üzerine Etkisi. Uluslararası Hematoloji-Onkoloji Dergisi. 2006; 3(16): 108-120. 14. Pınar S, Algier L, Çolak M, Ayhan A. Jinekolojik Kanserl Hastalarda Yaşam Kalitesi. Uluslararası Hematoloji-Onkoloji Dergisi. 2008; 3(18): 141-9.

15. Kimura CA, Kamada I, Guilhem D, Monteiro PS. Quality Of Life Analysis İn Ostomized Colorectal Cancer Patients. J Coloproctol. 2013; 33(4): 216221.

16. Sarenmalm EK, Öhlen J, Jonsson T, GastonJohansson F. Coping with Recurrent Breast Cancer: Predictors of Distressing Symptoms and HealthRelated Quality of Life. Journal of Pain and Symptom Management. 2007; 34(1): 24-39.

17. Rab F. Social Support as a Determinant of Health 
Related Quality of Life in Breast Cancer Survivors in California. Master of Sciences, The University of Western Ontario, London, Ontario, Canada: 2012.

18. Kızılcı S. Kemoterapi Alan Kanserli Hastalar Ve Yakınlarının Yaşam Kalitesini Etkileyen Faktörler. C. Ü. Hemşirelik Yüksekokulu Dergisi, 1999, 3 (2): 18-26.

19. Heydarnejad MS, Dehkordi H, Dehkordi S. Factors Affecting Quality Of Life in Cancer Patients Undergoing Chemotherapy. African Health Sciences. 2011; 11(2): 266-70.

20. Gökgöz S, Sadikoglu G, Paksoy E, Guneytepe U, Özçakır A, Bayram N, Bilgel N. Health Related Quality of Life among Breast Cancer Patients: A Study from Turkey. Global Journal of Health Science. 2011; 3(2): 140-52.

21. Salonen P. Quality of Life in Patients with Breast Cancer. Academic Dissertation. Unıversity Of Tampere, Finland: 2011.

22. Novothny P, Smith DJ, Guse L, Rummans TA, Hartmann L, Alberts S, Goldberg R, Gregory D, Johnson M. Sloan JA. A Pilot Study Assessing Social Support Among Cancer Patients Enrolled On Clinical Trials: A Comparison Of Younger Versus Older Adults. Cancer Management and Research. 2010; 2: 133-42.

23. Luszczynska A, Pawlowska I, Knoll N, Scholz U. Social Support And Quality Of Life Among Lung Cancer Patients: A Systematic Review. PsychoOncology. 2013; 22: 2160-2168.

24. Yamada TH. The Relationship Between Social Support, Optimism, And Cognition İn Breast Cancer And Non-Hodgkin's Lymphoma Survivors. Doctor of a thesis, The University of Iowa, Iowa City, 2011.

25. Özyurt BE. Kanser Hastalarının Algıladıkları Sosyal Destek Düzeyine İlişkin Betimsel Bir Çalışma. Kriz Dergisi. 2014; 15 (1): 1-15.

26. Uysal N. Baş Boyun Kanserli Hastalarda Fonksiyonel Durum ve Sosyal Desteğin
Belirlenmesi. Yüksek Lisans Tezi, Gazi Üniversitesi, Ankara: 2011.

27. Naseri N, Taleghani F. Social Support in Cancer Patients Referring To Sayed Al-Shohada Hospital. Iranian Journal of Nursing and Midwifery Research. 2012; 17(4): 279-83.

28. Doğan N. Akciğer Kanserli Hastalarda Yaşam Kalitesi ve Sosyal Destek. Yüksek Lisans Tezi, Atatürk Üniversitesi, Erzurum: 2011. 